\title{
Development of Integrated System and Synchronization of Data Study Program with Higher Education's External Quality Assurance System
}

\author{
Antonius P.G Manginsela \\ Electrical Engineering Department \\ Manado State Polytechnic \\ Kampus Polytechnic Ds.Buha \\ Manado-Indonesia
}

\author{
Marike A.S. Kondoj \\ Electrical Engineering Department \\ Manado State Polytechnic \\ Kampus Polytechnic Ds.Buha \\ Manado-Indonesia
}

\author{
Maksy Sendiang \\ Electrical Engineering Department \\ Manado State Polytechnic \\ Kampus Polytechnic Ds.Buha \\ Manado-Indonesia
}

\author{
Muhammad K. Bakary \\ Administration Bussiness Department Manado State Polytechnic \\ Kampus Polytechnic Ds.Buha Manado-Indonesia
}

\begin{abstract}
The study program as a business process implementing unit of a university is an indicator of the success of the process and the output of the higher education institution. A good data management of the tri-dharma are processe and integrated with the needs of external parties is very important in improving the quality of processes and products/graduates which will lead to increased satisfaction and trust from the stakeholders. The internal and external quality assurance mechanisms of higher education carried out by utilizing information technology are expected to provide a competitive advantage due to efficiency and effectiveness in various levels of the tri-dharma namely education, research, and community service.
\end{abstract}

It is necessary to align the strategic objectives of the organization with the determination of information needs. Analysis and development of information systems by business strategy is required for the implementation of information technology in the quality assurance mechanism which is carried out by the quality control team daily. So that the output of information from the information system can be presented for the needs of monitoring and evaluating study program coordinator at the department to the institutional level. Therefore, it can better prepare institutions to face external quality assurance mechanisms such as accreditation with the availability of real-time and well-organized data and information. For this reason, the need for synchronization and integration between internal and external applications is very important. Interoperability problems between internal systems and external systems can be overcome by implementing Service Oriented Architecture and web services. So that the use of information technology that has the advantages of efficiency and effectiveness can be carried out to support the activities of the Quality Control Team to determine, monitor, evaluate, control, and improve every process and output in higher education.

\section{General Terms}

Information technology, web programming, decision support

\section{Keywords}

Synchronization, quality control, higher education

\section{INTRODUCTION}

Good administration of study program's data in a higher education is very important. Data and information in a study program include data on educational processes, research, community service, cooperation and various other data as a result of the study program's activities carrying out its business processes. Appropriate data management and in accordance with the internal and external needs of higher education will provide benefits and continuous improvement for better services to stakeholders. Study program, hereinafter referred to as PS, is a unit of education and learning activities that have a certain curriculum and learning method in one type of academic education, professional education, and/or vocational education.

As a university business process management unit that is required to implement the regulations and policies set by the Indonesian government, including the quality assurance system. According to the regulation of the Minister Of Education And Culture number 3 of 2020 article 3 paragraph 2, concerning National Education Standards requires higher education institution to develop and implement an internal quality assurance system and become the basis for determining the criteria for an external quality assurance system through accreditation. In implementing the quality assurance system internally in it so that quality improvement and improvement can be carried out in a sustainable manner, a control circle (QCC) is formed that works in the PS environment. QCC is a small group within a work unit that carries out quality control in the same work unit, continuously being part of quality control for development and selfimprovement together by conducting exercises, using quality control techniques by involving all members who participate. [2]. Quality Control Circle, hereinafter referred to as QCC, is one of the methods used to solve a problem in the quality improvement process. In carrying out its duties, GKM carries out business process monitoring activities, namely tri-dharma activities in PS and measurement of process satisfaction and product results, in this case graduates of the study program. Starting from data on new student admissions, educational data includes learning processes and performance, evaluation, monitoring and educational output data such as the number of graduates and graduate tracking results. In line with the current implementation of the tri-dharma, the process data and 
results of research and community service must be managed and reported as a component of the study program performance assessment that must be reported to the university's external quality assurance mechanism, in this case the National Accreditation Board for Higher Education or Independent Accreditation Agency. This research is one part of the research that will be developed for the purposes of PS accreditation from an accrediting agency, where an integrated GKM system will be developed for integration and synchronization of PS data with data and information required by higher education accreditation institutions.

Currently, the activities of the internal quality assurance system are based on the implementation of the activity cycle abbreviated as PPEPP, namely Penetapan (P) or Determination, Pelaksanaan $(\mathrm{P})$ or Implementation $(\mathrm{P})$ Standards, Evaluasi (E) or Evaluation (E), Pengendalian (P) or Control and Peningkatan $(\mathrm{P})$ or Improvement $(\mathrm{P})$ Higher Education Standards as a whole system need to be evaluated and then developed on an ongoing basis. The implementation output in a cycle is submitted by the higher education to the Independent Accreditation Institute to request Study Program Accreditation (SPA) and obtain a study program accreditation rank or the National Accreditation Board for Higher Education (BAN-PT) to request Higher Education Accreditation (HEA) and get a college accreditation rating. QCC plays a role in Evaluation $(\mathrm{E})$ and Control $(\mathrm{P})$ activities for Determination $(\mathrm{P})$ and Implementation activities to obtain appropriate and appropriate Improvements $(\mathrm{P})$ so that they can provide data and information for accreditation of study programs and higher education. The Study Program Accreditation Instrument currently uses IAPS 4.0 in which there are guidelines for Compiling Self-Evaluation Reports (LED), Guidelines for Compiling Study Program Performance Reports (LKPS), Assessment Guidelines and Assessment Matrix. The existence of these instruments requires the management of accurate and precise data and information on the implementation of evaluation and control by QCC of study program. Therefore, it is necessary to use information technology in the management of PS data and information that can meet the needs of internal and external stakeholders. Information technology (IT) has been able to increase effectiveness, efficiency, competitiveness, and support managerial activities of organizations including educational institutions.

Utilization of information technology, of course, needs the right approach to suit one of the strategic goals of higher education, namely increasing accreditation ratings and increasing stakeholder trust, namely the community and government. The form of the use of information technology is the development of an Information System for the Quality Control Cluster (GKM) at the Manado State Polytechnic (Polimdo), within the scope of the task of evaluating, controlling for quality improvement and tri-dharma services. Several literature studies were conducted in determining the methods, models and development strategies in order to produce an information system that is appropriate and in accordance with the strategic objectives of the institution. After determining the development model and strategy, then web-based computer applications are created that include the GKM tasks in the study program which are then integrated into the GKM integrated information system. The selection of the method to be used in the development of computer applications is also carried out in a literature review to obtain conformity with the information system development strategy.

\section{LITERATURE REVIEWS}

As described above in this study, a literature study was conducted to explore the methods and strategies that have been implemented previously in order to obtain the right methods and strategies in making this information system. The literature review is carried out in several sub-headings and keywords in this study which are described as follows to determine each of them.

\subsection{Quality Control Circle}

Quality Control Circle is one of the methods used to solve a problem in the quality improvement process. Quality itself is one of the characteristics of a product or service that is determined by consumers. QCC is a good step to make a quality improvement because improvement steps using GKM make it easier to find a solution to a problem since QCC formed from member of internal unit it self. This was also emphasized by Hayu Kartika in her literature study which states that the implementation of QCC is used to find out the cause of a problem and get a solution to solve the problem and greatly affect employee performance and satisfaction. QCC is also part of the Continuous Process Improvement, is small groups of employees ( $4-8$ peoples) who carry out quality control and improvement activities regularly, voluntarily and continuously in their fields of work by applying quality control principles and techniques. An educational organization should always develop strategies that are adapted to the demands and needs of the environment in order to be able to survive and compete with other educational organizations. To achieve this, in order to achieve global competitiveness in the world of education, it is appropriate to carry out continuous improvement in various components of education management so as to be able to meet the demands of stakeholders who are used as benchmarks or standards in order to achieve global competitiveness. The continuous quality assurance of higher education is carried out through the stages which are arranged in a process as follows. (a) Establish the vision and mission; (b) Based on the vision and mission, each study program establishes the vision and mission of its study program; (c) The vision of each study program is then translated by the relevant study program into a series of quality standards for each quality item as mentioned above; (d) Quality standards are formulated and determined by concluding the university's vision (deductively) and the needs of stakeholders (inductively). As a standard, the formula must be specific and measurable, which contains elements of ABCD (Audience, Behavior, Competence, Degree); (e) Establish the organization and work mechanism of quality assurance; (f) Implement quality assurance by implementing the quality control management below; (g) Evaluate and revise quality standards through benchmarking on an ongoing basis. The quality management system could improve the quality of higher education and can carry out existing processes more effectively and efficiently so as to reduce existing costs, which in turn can produce a affordable education.

\subsection{Integrated Information System}

The definition of an information system can be an organized combination of people, hardware, software, communication networks, data resources, policies and procedures that store, retrieve, transform, and disseminate information within an organization. People rely on modern information systems to communicate with each other using a variety of physical devices (hardware), information processing instructions and procedures (applications), communication channels (computer networks), and stored data (data base or data resources). 
Higher education institutions as an organization that has a large and various kind of service unit is required to work to serve management and students quickly and accurately, requires a solution that can improve service processes beyond just office automation. The complexity of work such as entering data, managing data, making reports, and so on that can no longer be done in the form of office automation which results in a lot of work that is not completed on time and disrupts the course of this organization's business processes, must be anticipated by implementing a system that can serve all of these needs quickly, efficiently, effectively, and at the same time increase competitiveness. The integrated information system model will be developed by defining the main entities of the higher education system. The main entity will relate to many processes in the system to achieve the entity's goals. In developing an integrated system, it is necessary to identify the main entity from the main activities of higher education, namely tri-dharma (education, research and community service). The main entities are students, lecturers and staff, while the work unit is the supporting unit. The process for students and lecturers produces data and information needed in the management and determination of institutional strategic policies.

\subsection{Information system planning strategy}

The term strategy in an information systems planning is more intended at a broad level of thinking about the organization of information systems and their integration with the rest of the company. A strategy must be coherent, consistent, and purposeful. Coherent means clear to IS businesses and organizations. Consistent means built to fit. purposeful means to fit various changes in various things that are and will occur in the organization. Currently it is difficult to separate aspects of information systems or information technology strategy from business strategy. Therefore, it is important to use tools and techniques of analysis and business strategic planning to ensure that the strategy formulation and planning approach is formulated into a business strategic management pattern. The strategy model developed by Ward and Pepard is a component of business strategy, so that in strategy development Information System/Information Technology which is part of the business strategy process. The image of the information systems strategy model can be seen in the image below. This model consists of inputs, namely: (a) Internal business environment: current organizational conditions, goals (objectives), resources, processes; (b) External business environment: organizational environment, competition with other organizations. (c) Internal IS/IT environment: current IS/IT perspective on the organization, technology resources and infrastructure and (d) External IS/IT environment: technology trends in the organization's business. While the resulting outputs are: (a) Information Systems Business Strategy (b) IS/IT management strategy (c) IT strategy which is ultimately required in the development of the application portfolio. Application portfolio refers to an organization's collection of software applications and software-based services, which are used to achieve its goals or objectives.

\subsection{Synchronization Information Systems}

In line with the information system strategy process that applies a business model to the organization as part of a business strategy that is implemented in the form of a collection of interacting applications that will be developed in this research and those that already exist, such as the application of an external guaranteed system, namely the Online Higher Education Accreditation System (SAPTO). National Accreditation Board for Higher Education (BAN-
PT) which synchronizes with the Higher Education Database application (PD-Dikti) of the Ministry of Education, Culture, Research and Technology. Each system that is built has a different architecture, the type of database used, the naming of the tables in the database, and the structure of the different table attributes. Also there are no other system access rights to be able to access directly by querying other databases because of privacy and security. So there are obstacles to integration. Another thing that must be considered is the use of various equipment in accessing these applications. So that multiplatform factors must also be considered in application design.

A business process is a series of activities. employees, computers, and software systems perform activities. They are called service providers, or, for short, service. Each service is capable of performing several tasks. Business processes act as triggers asking service providers to perform certain tasks thus, services become business building blocks. This is known as Service Oriented Architecture (SOA). Service Oriented Architecture (SOA) is a method or technology used for enterprise integration. This enterprise integration includes integration within the enterprise (intra-enterprise integration) and across the enterprise (inter-enterprise integration or B2B). SOA as a technology can be implemented into various platforms.

\subsection{Application development}

Synchronization between applications in the prerequisite for QCC information system development which consists of several services (intra-enterprise integration) and synchronization (inter-enterprise integration) with information systems from outside the Manado State Polytechnic, namely the Online Higher Education Accreditation System (SAPTO) of National Accreditation Board for Higher Education (BANPT) which synchronizes with the Higher Education Database application (PD-Dikti) of the Ministry of Education, Culture, Research and Technology using a service-centered architecture or Service Oriented Architecture. Some things that need to be considered in the design issue of the SOA system are: (a) How a service encapsulates logic; (b) How the services relate to each other; (c) How services communicate with each other.

Basically, a service in SOA is an application. A service in SOA can be a web service application. SOA must be embodied in practice and web services are widely regarded as the way to make it happen. The other three basic standards are specific to Web Services and were the first to be defined: (a)WDSL; (b) SOAP. (c) UDDI; The setting of standards and protocols used in web services will depend on the technology infrastructure they have.

\section{RESEARCH METHODS}

In this study, several methods and analysis of the determination of the strategic plan of the GKM information system were used, SOA methods, Web Service standards and procedures and the last stage was the development of applications after a literature study was carried out. As a systematic, controlled and empirical investigation of a set of hypotheses built from a theoretical structure.

The initial step is to establish the PPEPP cycle, namely Determination (P), Implementation (P) Standards, Evaluation (E), Control (P), Improving (P) Internal Quality Assurance Systems in the main activities of higher education, namely tridharma (education, research and community development). This process carried out by the work unit managing the main 
entity (Students, Lecturers and Staff), namely the Study program. In accordance with the ongoing business process, gradually upwards to the department or UPPS (Study Program Management Unit), the Quality Assurance Center as the unit in charge of Quality Assurance at the institutional level and management consisting of the Senate, Director and Deputy Director.
Followed by redefining the business process model of the Quality Control Group based on the SPMI Cycle that has been defined above based on the vision, mission, goals \& objectives of the institution as well as the latest government regulations and policies. This study uses a framework that was compiled with reference to the literature review conducted on Ward and Peppard's books.

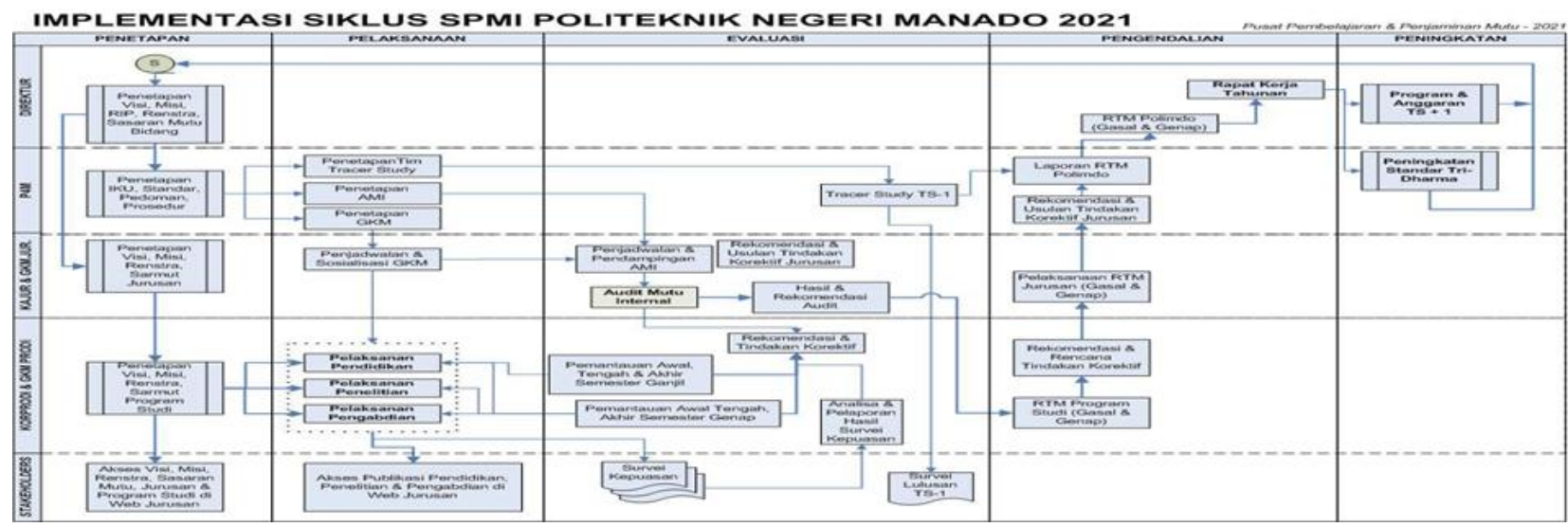

Fig 1 :Diagram of Internal Quality Control System's ccle at the process unit layer

\subsection{QCC Business Strategy}

The Critical Success Factor method is used in determining the QCC Business Strategy. The role of CSFs in strategic planning is as a connection between the organization's business strategy and its information system strategy, focusing the information system strategic planning process on strategic areas, prioritizing information system application proposals and evaluating information system strategies, CSFs analysis is a provision of the organization and its environment influencing success or failure. CSFs can be defined if organizational objectives have been identified. The purpose of CSFs is to interpret the objectives more clearly to determine what activities must be performed and what information is required. The role of CSFs in strategic planning is as a liaison between the organization's business strategy and its information systems strategy, focusing the information system strategic planning process on strategic areas, prioritizing proposed information system applications and evaluating information system strategies.

\subsection{Information Needs Analysis}

Value Chain Concept Method developed by Michael Porter. Map a company as a series, chain, or network of basic activities that add value to its products and services and thereby add a margin of value to the company and its customers. In the value chain conceptual framework, several business activities are the main processes; the other is the support process. The main processes are business activities that are directly related to the manufacture of products or the delivery of services to customers. In contrast, support processes are business activities that help support day-to-day business operations and that indirectly contribute to an organization's products or servicesthe organization's business strategy and its information systems strategy, focusing the information system strategic planning process on strategic areas, prioritizing proposed information system applications and evaluating information system strategies.

\subsection{Analysis of information systems and information technology requirements}

Service Oriented Architecture (SOA) is a form of architectural technology that follows the principles of service orientation (service orientation). This service-orientation concept takes an approach by dividing a big problem into a set of small services that aim to solve certain problems. After all problems can be divided into several services, the solution to these problems must be solved by allowing all services to participate in an orchestration. For that there are several problems that must be owned by the service, namely how the service relates, how the service communicates, how the service is designed, and how messages between services are defined. SOA consists of four components, namely: (a) Message, namely data needed to complete a part or a work unit, which is exchanged between one service and another; (b) Operations, which are functions owned by a service to process messages to produce something. These functions will interact with each other to complete a work unit; (c) Service, representing a set of related operations to complete a set of related work units; (d) Process, is a business rule that determines which operations are used to achieve certain goals.

\subsection{Design Implementation}

Prototyping or prototype is the initial form of the system that describes the final form of a system, so that it can make it easier for users to interact and evaluate the system that is being created. User involvement in the process can provide benefits in providing a replica of the system that will run, accommodating input from users for system perfection. Users will be more ready to accept any changes to the system that develops in accordance with the running of the prototype to the final results of development that will run later. The system can be added or reduced according to the development process. The step-by-step progress can be followed directly by the user. This method can provide resource and time savings in producing better and more efficient products for users. The process of making this prototype is to define the rules at an early stage, namely developers and users must have an understanding that the prototype is built to define initial requirements. The prototype will be removed or added to its 
part so that it is in accordance with the planning and analysis carried out by the developer until the trials are carried out simultaneously along with the development process.

There are four main prototyping methodologies, namely: (a) Illustrated, generating sample reports and screen displays; (b) Simulated, simulating some system workflows but not using real data; (c) Functional, simulating some actual system flow and using real data; (e) Evolutionary, produces a model that becomes part of the operational system.

\section{RESULT DAN DISCUSSION}

The figure below shows a diagram of the information system planned and implemented in which there are six application prototypes, namely: (a) PS Performance, (b) Internal Quality Audit, (c) Tracer Study, (d) PS Accreditation, (e) PS Cooperation, ( f) Stakeholder Satisfaction Survey. This information system interacts in the form of data exchange with Academic IS, Research \& PkM SI and PD-DIKIT Polimdo SI. Synchronization of data with an external quality assurance system is carried out through the PD-DIKTI Polimdo application which periodically according to the accreditation period of a study program is accessed by the Online Higher Education Accreditation System (SAPTO) application, the National Accreditation Board for Higher Education (BAN-PT)

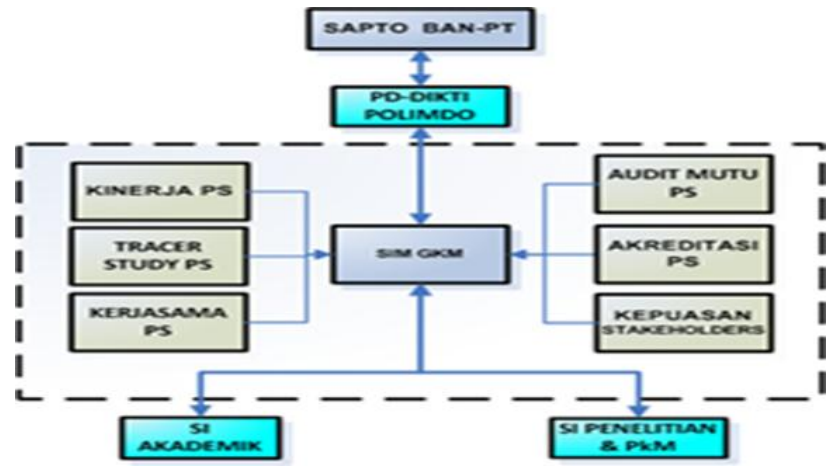

Fig 2. integrated information system Diagram

All SI-GKM applications in this study as an ongoing activity were made in prototype form to be adjusted according to user opinions. This makes it very easy for users to interact and evaluate the system that is being created. User involvement in the development process can provide benefits in providing a replica of the system that will run, accommodating input from users for system perfection. On the developer side, the prototype system is used to conduct synchronization trials between databases.

SI GKM is a homogeneous system, meaning that it is a distributed database system that connects DBMSs of the same type, compatible, with the same structure and data description . Then interact with DBMS from SI-Academic, SI-Research and PD-Dikti Polimdo heterogeneously, namely an incompatible DBMS is a heterogeneous system that is connected to a web-service, which is a set of operating functionality that can be accessed in a network via standardized XML messages. . Extensible Markup Language (XML) is a markup language, which uses tags to mark, categorize, and organize specific information. Markup describes a document or data structure and organization. Content, such as text, images, and data that contains a lot of markup tags. To facilitate database access, the six DBMSs in SI-GKM were merged into one database container. Due to the difference in data structure with SI-Academic, SI-Research requires a mapping process first before being entered into the PD-Dikti Polimdo database feeder. The database mapping (table mapping) is similar in structure to the PD_DIKTI feeder database which is accessed by SAPTO-BAN PT (External System).

The relationship between the Web Service Client and the request (request) and the Web Service Provider (response) occurs between the internal and external databases, then inserts, updates, and deletes the previously merged data to synchronize data. A very important step in this synchronization process is Auth/Validation, which is used to obtain security (get token). The token is obtained from the username password given by the SI-Academic, SI-Research \& PkM operators and PD-Dikti Polimdo, validation is used as a session to assess the validity of a data. After the data is appropriate and valid, it is then sent to the Ministry level PDDIKTI feeder application which has been synchronized with the SAPTO BAN PT application.

\section{CONCLUSION}

Integrated and synchronized data processing of quality control groups with external data requirements for accreditation can contribute to the strategic objectives of the institution. The stages of aligning the development of an information system that are compiled and integrated with business processes and organizational strategic plans so that they can support the organization to achieve the goals that have been set will determine the success of the implementation of the information system and the efficiency and effectiveness of the implementation of GKM tasks in improving the quality of processes and services in universities.

\section{REFERENCES}

[1] Kementerian Pendidikan Dan Kebudayaan, "Peraturan Menteri Pendidikan dan Kebudayaan No.3 Tahun 2020," Jakarta, 2020

[2] R. A. AZIZ, Total Quality Management: Tahapan Implementasi TQM dan Gugus Kendali Mutu Usaha Mikro Kecil Dan Menengah (UMKM), BandarLampung: Darmajaya ( DJ ) Press, 2019.

[3] H. Kartika, "Perbaikan Kualitas Dengan Menggunakan Gugus Kendali Mutu," Jurnal Ilmu Teknik dan Komputer ISSN 2548-740X, vol. 1, no. 1, p. 1, 2017.

[4] K. P. d. K. RI, "Peraturan Menteri Pendidikan Dan Kebudayaan Republik Indonesia Nomor 5 Tahun 2020 Tentang Akreditasi Program Studi Dan Perguruan Tinggi," Kementerian Pendidikan dan Kebudayaan RI, Jakarta, 2020.

[5] Direktorat Pendidikan Tinggi Vokasi dan Profesi, "Sistem Penjaminan Mutu Internal Perguruan Tinggi Penyelenggara Pendidikan Vokasi," Kementerian Pendidikan dan Kebudayaan, Direktorat Jenderal Pendidikan Vokasi , Jakarta , 2020.

[6] Badan Akreditasi Perguruan Tinggi, "Peraturan Badan Akreditasi Nasional Perguruan Tinggi Nomor 5 Tahun 2019 Tentang Instrumen Akreditasi Program Studi," BAN-PT, Jakarta, 2019.

[7] U. R. Q. O. A. M. H. Henderi, "Dashboarding Information Systems For The Education Sector : Aplication And Methodologies," ejournal Universitas Raharja, vol. 5, no. 1, p. 1, 2011.

[8] U. a. M. R. Devi, "Quality Assurance in Education through Quality Circles - Global and Indian Context," 
Academic Leadership: The Online Journal, vol. 7, no. 4, p. 25,2009 .

[9] T. Rachman, "Universitas Esa Unggul," 23 November 2017. [Online]. Available: http://taufiqurrachman.weblog.esaunggul.ac.id/category/ ema503-manajemen-kualitas/. [Accessed 21 March 2021].

[10] A. Widiansyah, "Penjaminan Mutu: Penerapan, Pemenuhan, Dan Pengendalian Standar Mutu Serta Implementasinya Dalam Dunia Pendidikan," Cakrawala, vol. 19 , no. No.2 September, p. 189-194, 2019.

[11] J. S. Suroso, "Quality Management System (QMS) In Higher Education: Towards Quality And Affordable Education," in 2nd International Seminar on Quality and Affordable Education (ISQAE 2013)., . Kuala Lumpur, 2013.

[12] J. A. O. \&. G. M. Marakas, Introduction To Information Systems, New York: McGraw-Hill/Irwin, 2010.

[13] I. Isnandar Agus, "Perencanaan Strategis Sistem Informasi Administrasi yang Terintegrasi Pada Lembaga Pendidikan Tinggi," JUPITER, vol. 9 , no. 2 Bulan 10, pp. 29 - 34, 2017.

[14] D. S. P. Iping Supriana Suwardi, "New Integration Model of Information System on Higher Education Institution," in International Conference on Electrical Engineering and Informatics, Institut Teknologi Bandung, Bandung, 2007.

[15] A. Cassidy, A Practical Guide to Information Systems Strategic Planning, Boca Raton, Florida: Auerbach Publications, 2006.

[16] J. W. A. J. Peppard, Strategic Planning for Information Systems, Third Edition, West Sussex: John Wiley \& Sons Ltd, 2002.

[17] LeanIX , "The Definitive Guide to Application Portfolio Management," LeanIX GmbH, Bonn, Germany, 2018.

[18] B. B. \&. K. Gabhart, Service Oriented Architecture Field : Guide for Executives, West Sussex: John Wiley \& Sons, Inc., 2012.
[19] W. H. Utomo, Pemrograman Aplikasi SOA, Salatiga: UKSW Press, 2012.

[20] T. Erl, Service-Oriented Architecture: Concepts, Technology, and Design, New Jersey: Prentice Hall PTR, 2005.

[21] N. M. Josuttis, SOA in Practice, Sebastopol, CA: O’Reilly Media, Inc., 2007.

[22] P. Widyaningshi , Mustafid and A. F. Rochim, "Perencanaan Strategis Sistem Informasi Pada Institusi Pendidikan Tinggi Menggunakan Analisis Critical Success Factors," Jurnal Sistem Informasi Bisnis, vol. 2, no. Agustus, pp. 87-93, 2011.

[23] D. Purnomo, "Model Prototyping Pada Pengembangan Sistem Informasi," JIMP - Jurnal Informatika Merdeka Pasuruan, vol. 2 , no. 2 , pp. 54-61, 2017.

[24] P. M. Ogedebe and P. J. Babatunde, "Software Prototyping: A Strategy to Use When User Lacks Data Processing Experience," ARPN Journal of Systems and Software, vol. 2, no. 6, pp. 219-224, 2012.

[25] Badan Akreditasi Perguruan Tinggi Perguruan Tinggi (BAN-PT), "Peraturan Badan Akreditasi Nasional Perguruan Tinggi Nomor 2 Tahun 2017 tentang Sistem Akreditasi Nasional," BAN-PT, Jakarta, 2017.

[26] P. Roger S. Pressman, Software Engineering, A Practitioner' S Approach, Seventh Edition, New: McGraw-Hill -Higher Education, 2010.

[27] Muhamad Fatkhur Rohim, "Integrasi Antar Sistem Informasi Yang Heterogen Menggunakan Metode Web Service SOAP," rogram Studi Teknik Informatika - S1, Fakultas Ilmu Komputer, Universitas Dian Nuswantoro, Semarang, 2018.

[28] T. Erl, Service-Oriented Architecture Second Edition, Upper Saddle River, New Jersey: Prentice Hall, 2017. Ding, W. and Marchionini, G. 1997 A Study on Video Browsing Strategies. Technical Report. University of Maryland at College Park. 